\title{
Tehergépjárművek menetadatainak elemzése egy meghatározott szállítási útvonalon
}

\section{Analysis of Driving Data of Lorries on a Certain Route}

\author{
L. CZÉGÉ르, A. VÁMOSI ${ }^{2}$, I. KoCSIS ${ }^{2}$ \\ 1Debreceni Egyetem, Műszaki Kar, Gépészmérnöki Tanszék, Debrecen, Ótemető u. 2-4, 4028 \\ ${ }^{2}$ Debreceni Egyetem, Műszaki Kar, Műszaki Alaptárgyi Tanszék, Ótemető u. 2-4, 4028
}

\begin{abstract}
Absztrakt. Ebben a tanulmányban egy állandó útvonalon közlekedő tehergépjármú mozgását leíró menetciklus létrehozását tárgyaljuk. Kiválasztottunk egy jellemző szállítási útvonalat, ahol olyan tehergépjármüvek közlekednek, melyek fel vannak szerelve megfelelő adatgyưjtő berendezéssel. Hosszú távon gyüjtöttük a jármú mozgását leíró adatokat, majd az adatokat egy saját fejlesztésú célszoftver segítségével szürtük és készítettük elö, végül a tisztított adatokat statisztikai eljárások alkalmazásával dolgoztuk fel.
\end{abstract}

Abstract. In this paper the development of a driving cycle for lorries traveling a certain route is presented. A typical transportation route has been selected, which used by lorries instrumented with the proper data-collecting equipment. We used these on-board units to collect data over a long time period in the real-life traffic. We filtered the collected data, and carried out a statistical evaluation on the basis of the measured data.

Kulcsszavak: menetciklusok, közlekedési menetadatok, statisztikai elemzés, vehicle driving patterns.

\section{Bevezetés}

A műszaki gyakorlatban általánosan elterjedt eljárás, hogy a károsanyag-kibocsátás és az energiafelhasználás meghatározásához a járműveket olyan teszteljárásoknak vetik alá, melyek során a jármű - fogyasztással összefüggésbe hozható - igénybevétele hasonló a valós közlekedési viszonyok között fellépő igénybevételekkel. A gyakorlatban a valós igénybevételeket szimuláló terhelést úgynevezett menetciklusok formájában adjuk meg [1]. A menetciklus elsősorban az adott útvonalra jellemző függvény, amely a jármű sebességének változását írja le az idő függvényében [2]. Attól függően, hogy milyen valós helyzetet kell szimulálni, más és más menetciklusok tudják reprezentatív módon leképezni a valós igénybevételt. A szakirodalomban általánosan elfogadott, hogy a károsanyagkibocsátás és energiafelhasználás pontos meghatározásához olyan menetciklusokra van szükség, melyek az általános érvényű menetciklusoknál (pl. WLTC) jobban reprezentálják az adott régió, város, vagy felhasználási mód jellemző igénybevételét [3] [4].

Egy nagyobb volumenű projekt részeként felmerült az igény, hogy olyan menetciklusokat állítsunk elő, melyek kellő pontossággal reprezentálják egy tehergépjármű egy-egy kijelölt útszakaszát. Ennek a dolgozatnak az a célja, hogy egy esettanulmányon keresztül megvizsgálja, hogy a rendelkezésre álló jármű menet adatokat hogyan tudjuk felhasználni, és milyen eljárást célszerű alkalmazni a kívánt menetciklusok előállítására. Kiválasztottunk egy jellemző szállítási útvonalat, ahol olyan 
tehergépjárművek közlekednek, melyek fel vannak szerelve megfelelő adatgyűjtő berendezéssel. A fedélzeti adatgyűjtő eszközökkel hosszú távon gyűjtöttük a jármű mozgását leíró adatokat (helyzet, megtett út, pillanatnyi sebesség, stb.), majd ezeket az adatokat statisztikai eljárások alkalmazásával dolgoztuk fel.

\section{A vizsgált útvonal}

A bemutatott vizsgálat egy meghatározott útvonalhoz kapcsolódik, mely Debrecen két pontját köti össze. Az útvonal az alábbi utakat érinti: Vámraktár utca - Monostorpályi út - Mikepércsi út Wesselényi utca - Erzsébet utca - Nyugati utca - Kishegyesi út - Határ út. Az útvonal hossza 8,8 km, mely belvárosi és külvárosi szakaszokat egyaránt tartalmaz. Az adott útvonalon a hét minden napján (munkanapokon és hétvégén egyaránt) 4-5 alkalommal történik fémipari alapanyag beszállítás egy raktárból a gyártó üzembe, minden alkalommal ugyanazzal a nyerges vontatóból és félpótkocsiból álló járműszerelvénnyel, de több sofőrrel.

A vizsgálat elsődleges célja a jármű mozgásának elemzése annak érdekében, hogy a szállítási feladatra ki tudják választani az optimális járművet a szállítási költség, valamint a károsanyag-kibocsátás minimalizálására. Az elemzés a járművön elhelyezett GPS eszköz által gyűjtött, egy központi szerveren tárolt adatok alapján történt. Jelen vizsgálatban a hely (GPS koordináták: szélesség és hosszúság) és a sebesség adatokat használtuk fel, melyeket az eszköz meghatározott távolság (25 m) megtétele után automatikusan rögzít, vagyis az alapadatok helyhez (pozícióhoz) kötöttek.

\section{A jármü mozgásának kinematikai elemzése}

Első lépésként - mivel az eszköz folyamatosan mér - a nagyszámú adathalmazból ki kellett válogatnunk az adott útszakaszra vonatkozó méréseket. (Az útvonal a két telephely kapuja között értendő.) Vizsgálatunkba csak a raktárból a gyárba történő utazásokat vontuk be, ugyanis csak ekkor közlekedik rakottan a jármű. A szállítások időpontja minden nap közel azonos, így az időpontokat négy kategóriába tudtuk besorolni: délelőtti, délutáni, esti és éjszakai szállítás. A délelőtti és a délutáni szállítások részben vagy egészben csúcsidőben történnek, míg az esti és az éjszakai szállítások kisebb forgalmú időszakot érintenek. Az útvonalon nagy számban vannak közlekedési lámpával ellátott útkereszteződések, melyek napközben üzemelnek, de éjszaka ki van kapcsolva, így a négy időszak négy különböző paraméterrel jellemezhető időszakot jelent.

\subsection{Az eljutási idő elemzése}

A vizsgálat eredményeként egyrész a mozgásjellemzőkhöz (elsősorban a sebességhez és az időhöz) kapcsolódó statisztikai mutatószámok, másrészt a menetciklus kerültek meghatározásra teljes hétre, teljes napra, illetve a négy napszakra vonatkozóan.

Az eljutási idők vizsgálata a várt eredményt hozta: a délelőtti csúcsidőben 1302 s, a délutáni időszakban 1185 s, míg az esti és éjszakai órákban 1067 s és 851 s adódott. Ebből jól látható az átlagos eljutási időkben a járműforgalom nagyságának és a jelzőlámpák működésének szerepe. 

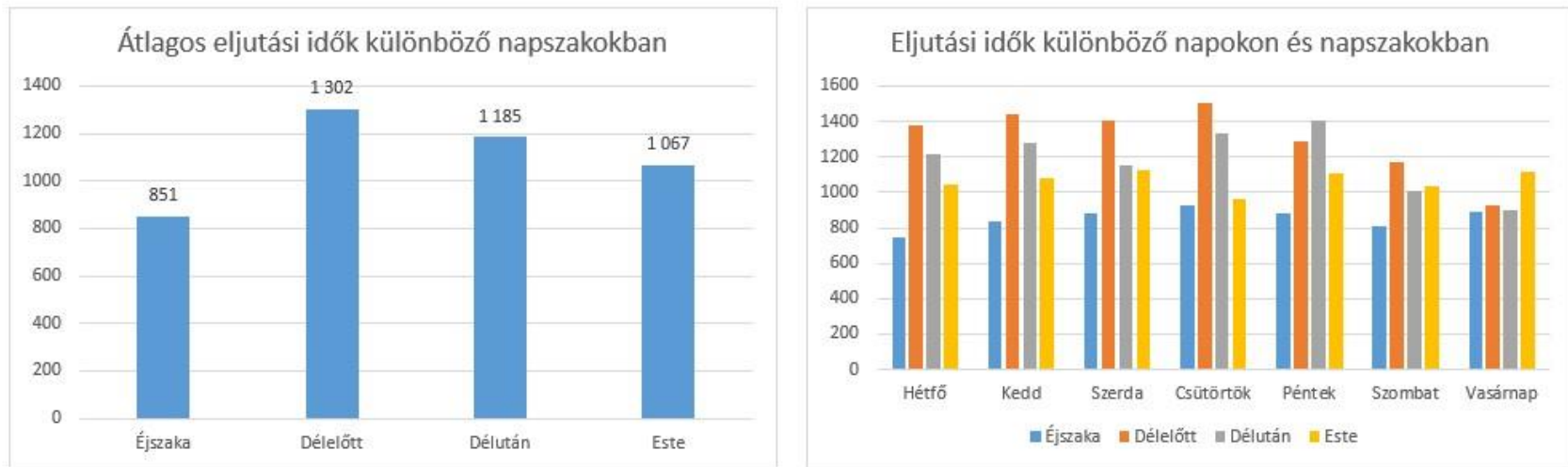

1. ábra. Az átlagos eljutási időtartamok az egyes napszakokban napi, illetve heti bontásban

Az útszakaszon a megengedett sebesség végig $50 \mathrm{~km} / \mathrm{h}$, nincsenek emelt vagy csökkentett sebességű szakaszok benne. Vizsgáltuk az érintett szakaszokon az eljutási idő változását is. A 2. ábrán jól látható az elméleti $50 \mathrm{~km} / \mathrm{h}$ sebességhez tartozó időhöz képeset az eljutási idők változása. A függőleges vonalak a szakaszhatárokat jelölik (itt a jármű irányt vált, jobbra vagy balra kanyarodik). A szakaszhatárok közötti időnövekedések (például a második és a hetedik szakaszban) a közbenső jelzőlámpák kapacitáshiányából adódó várakozásokat mutatják. Jól látható, hogy az éjszakai (jelzőlámpa nélküli időszak) szinte egyenes vonalához képest a többi időszakban a jelzőlámpák szinte mindig hosszabb-rövidebb várakozásra kényszerítik a járműveket.

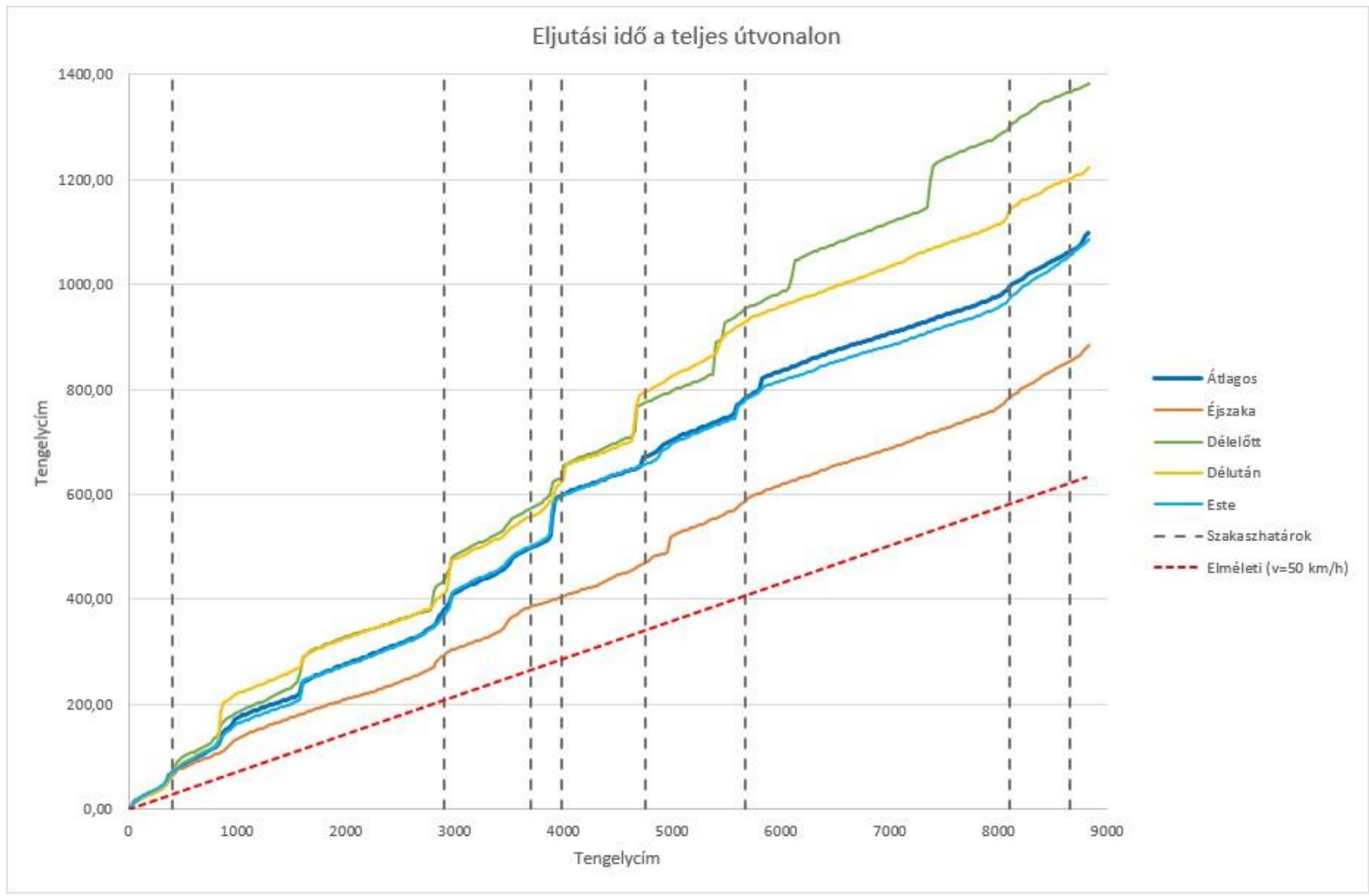

2. ábra. Az átlagos eljutási idôtartamok az egyes napszakokban a pozíció (megtett út) függvényében 


\subsection{A sebesség elemzése menetciklusokkal}

Elkészítettük az útszakaszra vonatkozó menetciklust is. A menetciklus (sebesség - idő diagram) az idő függvényében mutatja a sebesség pillanatnyi értékét. Az eljutási idők vizsgálatából látszik, hogy minden utazás más eljutási idővel ér véget, így a sebességértékeket inkább az útszakaszhoz (pozícióhoz) kell rögzíteni és az adott pozícióban mérhető átlagos időt, illetve sebességértéket kell vizsgálni. Az elemzés során kiderült, hogy az átlag helyett a medián értékek alkalmazása célravezetőbb, mert az kevésbé veszi figyelembe az egyszeri kiugró értékeket (például vészmegállás egy másik jármű miatt).

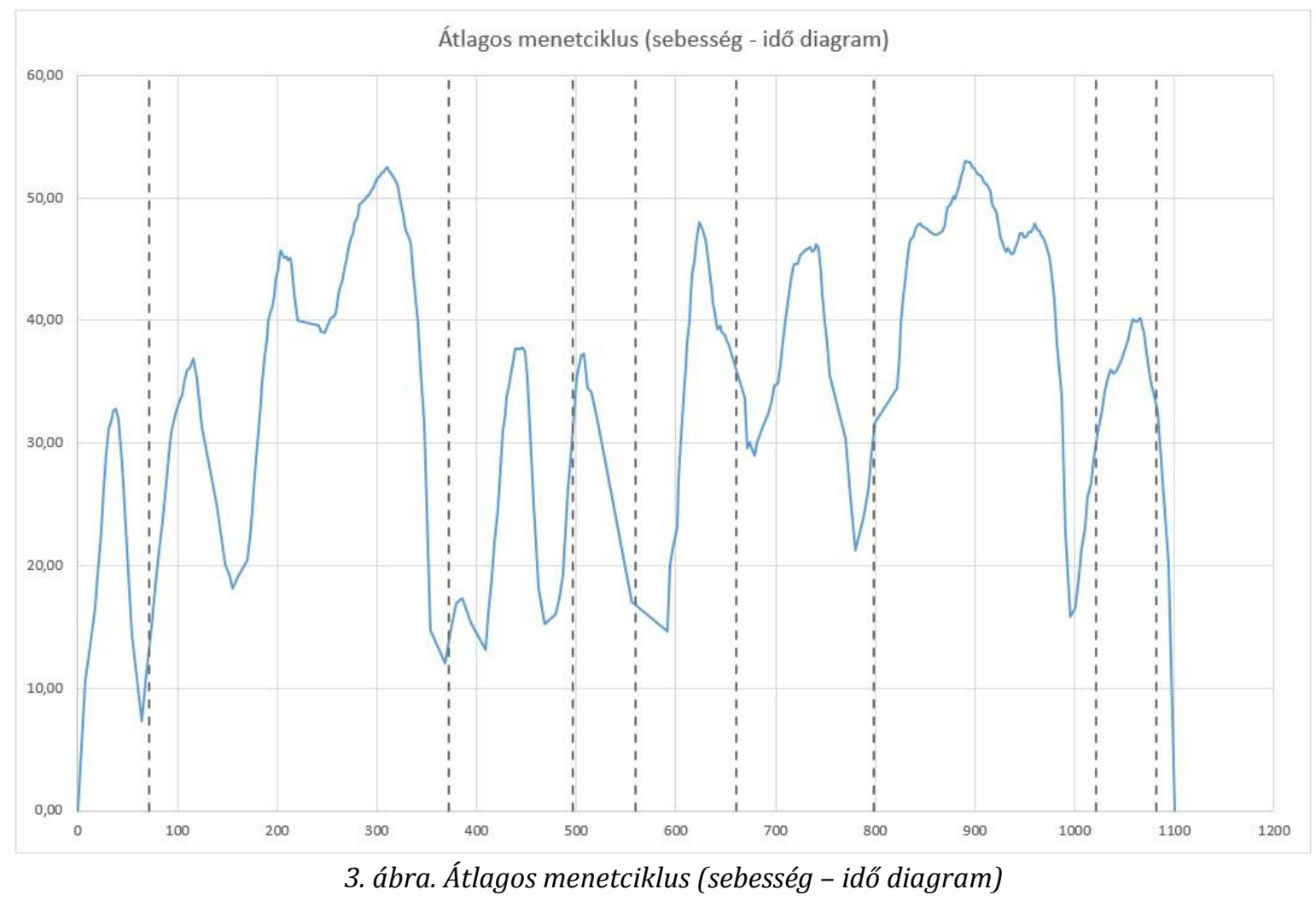

Ha a menetciklust a különböző napszakokban külön is elkészítjük és összevetjük azokat egymással, jól látható az eljutásidők (a ciklus hossza) változása, valamint a sebesség értékek ingadozása is. 

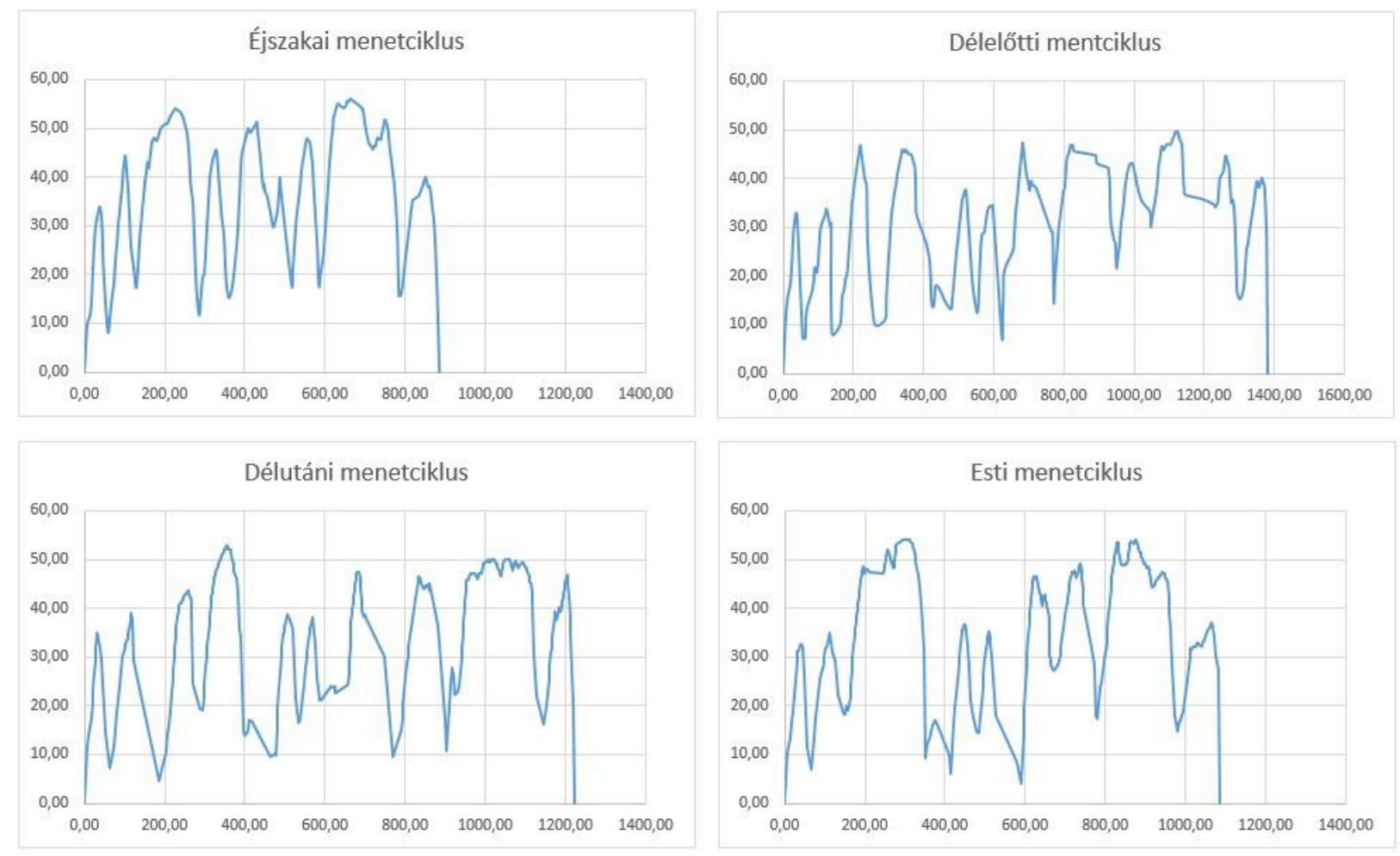

4. ábra. Átlagos menetciklusok napszakokra vonatkoztatva

\section{Összefoglalás}

A szállítás költsége, valamint a szállítás során kibocsátott károsanyag mennyisége alkalmazott jármű és a rakomány méretének megfelelő megválasztásával minimalizálható. Ehhez szükséges a szállítási útvonal elemzése, ezen belül a sebesség, a gyorsulás és az időtartam adatok statisztikai leírása, valamint a menetciklus előállítása.

Jelen tanulmányban egy meghatározott szállítási útvonal elemzését végeztük el a járművön elhelyezett GPS alapú mérőeszköz által gyűjtött, és központi szerveren tárolt valós forgalomban mért mozgásadatok alapján. A hét napjaira, és azon belül négy meghatározott időintervallumra (napszakra) jellemző adatok alapján kiértékeltük a különböző eljutási időket, valamint létrehoztuk a menetciklusokat. A kapott eredmények a továbbiakban az említett jármű dinamikai szimulációjához szolgáltatják majd a terhelést reprezentáló bemenő adatokat.

\section{Köszönetnyilvánítás}

A tanulmány alapjául szolgáló kutatást az Innovációs és Technológiai Minisztérium által meghirdetett Tématerületi Kiválósági Program ED_18-1-2019-0028 számon támogatta, a Debreceni Egyetem (Járműipar) tématerületi programja keretében. 
International Journal of Engineering and Management Sciences (IJEMS) Vol. 5. (2020). No. 2

DOI: 10.21791/IJEMS.2020.2.39.

\section{Hivatkozások}

[1] H.Y. Tong (2019) Development of a driving cycle for a supercapacitor electric bus route in Hong Kong, Sustainable Cities and Society, 48. 101588.

[2] Peng Yuhui, Zhuang Yuan, Yang Huibao (2019) Development of a representative driving cycle for urban buses based on the K-means cluster method, Cluster Computing. 22(3) pp. 6871-6880.

[3] S. Peihong, Z. Zhiguo, L. Jingwei, Z. Xiaowen (2018) Development of a typical driving cycle for an intra-city hybrid electric bus with a fixed route. Trans. Res. Part D: Transp. and Env. 59. pp 346360.

[4] A. Geetha, C. Subramani (2019) Development of driving cycle under real world traffic conditions: A case study, International Journal of Electrical and Computer Engineering (IJECE), V 9, pp. 4798-4803. 